\title{
The evaluation of parental material of winter rapeseed (Brassica napus L.) and winter brown mustard (Brassica juncea L.) on resistance to Phoma rot in the central zone of the Krasnodar region of the Russian Federation
}

\author{
Oksana Serdyuk*, Victoria Trubina, and Lyudmila Gorlova \\ V.S. Pustovoit All-Russian Research Institute of Oil Crops, Filatova street, 17, 350038 Krasnodar, \\ Russia
}

\begin{abstract}
In 2018-2020, Phoma rot (Leptosphaeria maculans Ces. \& De Not) in the form of stem canker was the most common disease on winter rapeseed and winter brown mustard in the central zone of the Krasnodar region of the Russian Federation. Given the high prevalence and development of the disease in all years of research, we identified the rapeseed samples resistant to it; they had the affection degree of 1-2 points (9.0-12.0 $\%$ of the total number of studied samples). The rest of the samples were weakly resistant with the affection degree of 3-4 points (33.0-39.0\% of samples), weakly susceptible with the affection degree of 5-6 points (28.0$40.0 \%$ of samples) and susceptible with the affection degree of 7-9 points (15 $0-23.0 \%$ of samples). We also identified the samples resistant to Phoma rot during the examination of mustard. Their number was lower than that of the rapeseed $-3.0-6.0 \%$ of the total number of samples. The main part of the samples was weakly resistant with the affection degree of 3-4 points (47.0-63.0 \% of the total number of samples). The rest of the samples during the years of research were weakly susceptible with the affection degree of 5-6 points (11.0-30.0\%) and susceptible (9.0-18.0\%). The parental material of winter rapeseed and winter brown mustard, resistant to disease, can be used as the donors of resistance to Phoma rot in breeding work during the development of the new promising varieties.
\end{abstract}

\section{Introduction}

Rapeseed (Brassica napus L.) and brown mustard (Brassica juncea L.) are the main representatives of the oil crops of Brassicacea family. In 2017, in Europe, the rapeseed production was $63 \%$ of total oil crops production. Both spring and winter forms of these crop are of value. The oil obtained from the seeds of rapeseed and mustard has a unique biochemical composition and is used not only for food purposes, but also as a biological fuel. The seed

\footnotetext{
*Corresponding author: oserduk@mail.ru
} 
meal of these crops is a source of fodder for farm animals, because it contains a large amount of protein [1-3]. It is balanced in amino acid composition, contains a large amount of fat, available nitrogen, and phosphorus. Mustard seeds and cake are used in medicine and as a seasoning [4]. In addition, rapeseed and mustard are used as a green manure crop [5].

Rapeseed and mustard may not always reach their yield potential due to disease damage during the growth season. The research carried out in the central zone of the Krasnodar region in recent years show that such diseases as Alternaria blight, Sclerotinia blight, Phoma rot, etc. are observed on winter rapeseed and winter mustard. One of the most dangerous diseases of winter rapeseed and winter mustard is Phoma rot, which manifests itself on the stems in the form of ulcers of various sizes and depths (stem canker). The stems dry out, the internal tissues turn into dust in the places of necrosis, the plants are lodging, which leads to significant losses in the yield of rapeseed and mustard - by 36.1 and $37.2 \%$, respectively [6]. Moreover, when mustard is affected, then, within a few days, the disease pathogen is able to metabolize phytoalexins, which are produced by the plant in response to contact with the phytopathogen (protective substances), thereby depriving it of protection from damage not only by this disease, but also by others [7].

Currently, there are chemical preparations from triazole and strobilurin groups, which effectively reduce the harmfulness of winter rapeseed stem canker and preserve the seed yield. They also exhibit grow-regulating characteristics, their use helps to inhibit plant growth, reduce internode elongation, increase the level of chlorophyll in tissues, increase the ratio of roots and shoots, delay plant aging, and increase antioxidant activity [8-10].

However, the most cost-effective and environmentally safe way to protect rapeseed and mustard from diseases is to cultivate resistant varieties. An important link in the breeding process is the evaluation of the parental material of these crops for resistance to Phoma rot, because it allows searching for resistance donors for the development of new varieties without loss of yield and the need to use chemical plant protection products. The evaluation must be carried out continuously, since the Phoma rot pathogen has a great virulence potential, and varieties with resistance genes become susceptible in 3-4 years [11, 12].

The aim of the work was to evaluate the parental material of winter rapeseed and winter brown mustard for resistance to Phoma rot as one of the most common and harmful diseases of these crops.

\section{Materials and methods}

We carried out the research in 2018-2020 at V.S. Pustovoit All-Russian Research Institute of Oil Crops (Krasnodar). The fungus Leptosphaeria maculans Ces. \& De Not, the pathogen of Phoma rot on Brassicacea crops (anamorphic stage of Phoma lingam (Tode) Desm) was the object of the study $[13,14]$.

We annually evaluated the parental material of rapeseed and mustard in the amount of 400 samples of each crop in the field against a natural infectious background. We carried out the last recording at the stage of yellow-green pod.

We determined the disease prevalence in the samples by the following formula:

$$
\mathrm{P}=\frac{\mathrm{n}}{\mathrm{N}} \quad 100 \%,
$$

where $\mathrm{P}-$ is the disease prevalence, $\%$;

$\mathrm{n}-$ is the number of affected plants in a sample, pcs;

$\mathrm{N}$ - is the total number of recorded plants in a sample, pcs.

We divided the diseases prevalence into low, average, and high:

- $\quad$ low - affected up to $10 \%$ of plants in a sample;

- $\quad$ average - affected 11-50\% of plants in a sample;

- $\quad$ high - affected $51 \%$ of plants in a sample and more. 
We determined the intensity of plant damage by Phoma rot using the following scale:

0 - a healthy plant;

1 point - a stem has single black spots of up to $3 \mathrm{~cm}$ in size;

2 points - a stem has elongated gray spots surrounded by a dark purple rim ranging in size from 3 to $5-6 \mathrm{~cm}$;

3 points - the affected areas on a stem merge into a necrotic surface of up to $10 \mathrm{~cm}$ and more with the presence of pycnidia on the affected surface, the tissues can be pressed through;

4 points - the tissues of more than $1 / 3$ of a stem are dry of light gray color with numerous pycnidia on the surface, the stem breaks easily.

We determined the Phoma rot development by the following formula:

$$
\mathrm{R}=\frac{\Sigma(\mathrm{ax} \mathrm{b})}{\mathrm{N} \times \mathrm{k}} \quad 100 \%
$$

where $\mathrm{R}-$ is the disease development, $\%$;

$\Sigma(\mathrm{a} \times \mathrm{b})-$ is the sum of the products of the number of affected plants (a) by the corresponding damage point (b);

$\mathrm{N}$ - is the total number of recorded plants (healthy and affected) in a sample;

$\mathrm{k}-$ is the highest point of affection.

We divided the disease development into low, weak, average, and strong:

- $\quad$ low - up to $10 \%$;

- weak - 11-30\%;

- $\quad$ average $-31-60 \%$

- $\quad$ strong $-61 \%$ and higher.

We carried out the evaluation of breeding samples of rapeseed and mustard for resistance to Phoma rot using a 10-point scale based on the abovementioned scales and formulas:

0 points - all plants are healthy;

1 point - up to $10 \%$ of affected plants with a low disease development;

2 points $-11-20 \%$ of affected plants with a low and weak disease development;

3 points $-21-30 \%$ of affected plants with a low, weak and average disease development;

4 points $-31-40 \%$ of affected plants with a low and average disease development;

5 points $-41-50 \%$ of affected plants with a low, average and strong disease development;

6 points $-51-60 \%$ of affected plants with an average and strong disease development;

7 points $-61-70 \%$ of affected plants with an average and strong disease development;

8 points $-71-80 \%$ of affected plants with a strong disease development;

9 points $-81-100 \%$ of affected plants with a strong disease development.

Using the presented scale, we divided all breeding samples of rapeseed and mustard into the following groups according to the degree of resistance:

0 points - immune;

1-2 points - resistant;

3-4 points - weakly resistant;

5-6 points - weakly susceptible;

7-9 points - susceptible [15].

We carried out the Phytoexamination of the affected parts of rapeseed and mustard plants in the laboratory conditions. We identified the pathogens in the laboratory conditions using a Motic VA300 microscope, at 40x magnification. 


\section{Research results}

As a result of examination of the phytosanitary condition of the breeding samples of winter rapeseed and winter brown mustard in 2018-2020, we revealed that the plants were affected by the following diseases: white rot (pathogen is Sclerotinia sclerotiorum (Lib.) De Bary.), powdery mildew (pathogen is Erysiphe communis Grev. f. brassicae Hammar L.), downy mildew (pathogen is Peronospora brassicae Gäum.), Alternaria blight (pathogens are $\mathrm{Al}$ ternaria spp), Phoma rot (pathogen is Leptosphaeria maculans Ces. \& De Not). We determined that the most common disease during the years of research was Phoma rot in the form of a stem canker.

On average, the prevalence and development of Phoma rot in breeding and seedgrowing sowings of winter rapeseed and winter brown mustard in the central zone of the Krasnodar region did not differ by the years of research (Table 1).

Table 1. The prevalence ( $\mathrm{P}, \%)$ and development (R, \%) of Phoma rot on winter rapeseed and winter brown mustard

\begin{tabular}{|l|c|c|c|c|}
\hline \multirow{2}{*}{ Year } & \multicolumn{2}{|c|}{ Winter rapeseed } & \multicolumn{2}{c|}{ Winter brown mustard } \\
\cline { 2 - 5 } & $\mathrm{P}$ & $\mathrm{R}$ & $\mathrm{P}$ & $\mathrm{R}$ \\
\hline 2018 & $2.5-67.5$ & $0.6-31.9$ & $11.0-62.0$ & $5.0-29.0$ \\
\hline 2019 & $10.0-72.0$ & $3.6-30.4$ & $15.0-77.0$ & $3.8-37.0$ \\
\hline 2020 & $10.0-80.0$ & $2.5-43.2$ & $5.0-63.0$ & $1.3-31.2$ \\
\hline
\end{tabular}

The intensity of development of phytopathogens and the rate of infection spreading depend on the susceptibility of the host plant, the deposit of infective matter in a place of the plant growth, and, to a greater extent, on the weather conditions prevailing during the growth season of the host plant: environment temperature, relative humidity and accumulated precipitation. The spring renewal of the growth season of winter rapeseed and winter brown mustard in the central zone of the Krasnodar region begins in late February-early March, and the harvesting takes place in the first ten days of July. Therefore, we studied the studied the weather conditions for the period of March-early July.

In 2018, for the period from March to the first ten days of July, the amount of precipitation by ten-day periods was small $(0.2-14.00 \mathrm{~mm})$, with the exception of the first ten days of May, when $26.0 \mathrm{~mm}$ precipitated. However, the relative humidity during this period was favorable for the development of the Phoma rot pathogen, amounting to 53-60\% by tenday periods. In combination with the air temperature exceeding the long-term annual average indicators by $1.7-3.4^{\circ} \mathrm{C}$, it contributed to the rather rapid spreading of the infective matter of Phoma rot. The prevalence of the disease on rapeseed was low to high, ranging from 2.5 to $67.5 \%$; the disease development varied from weak to average on different samples, amounting to $0.6-31.9 \%$. The disease prevalence on mustard was average and high $11.0-62.0 \%$, the disease development was weak and did not exceed $29.0 \%$.

In 2019, the weather conditions differed insignificantly by indicators from 2018. The average air temperature exceeded the long-term annual average indicators by 1.6-5.9 ${ }^{\circ} \mathrm{C}$. During the growth season of rapeseed and mustard, the amount of precipitation was evenly disturbed and amounted t0 13.0-39.0 mm, with the exception of the first and last ten days of May, and the second ten days of June, when the amount of precipitation was low (0-5.0 $\mathrm{mm})$. The relative humidity (59-72\%) was favorable for the development of pathogens. The disease prevalence on rapeseed was low to high, reaching 10.0-72.0\%, the disease development was from low to weak, amounting to 3.6-30.4\%. The Phoma rot prevalence on mustard was from average to high $-15.0-77.0 \%$, the disease development was from low to average $(3.8-37.0 \%)$. 
In 2020, the weather conditions were characterized by uneven precipitation. In the last ten days of May, the amount of precipitation exceeded the long-term annual average data by 3 times $(61 \mathrm{~mm})$, which led to an increase in the relative humidity to $73 \%$. The high relative humidity (70-77\%) lasted until the last ten days of June. In combination with the average air temperature $\left(21.0-24.4^{\circ} \mathrm{C}\right)$, optimal for the pathogens development, this contributed to an increase in the rate of Phoma rot spreading. The disease prevalence on crops varied from low to high, amounting to $10.0-80.0 \%$ for rapeseed and $5.0-63.0 \%$ for mustard. The disease development on rapeseed also had a wide range (from low to average) and varied from 2.5 to $43.2 \%$. The disease development on mustard was slightly lower - from 1.3 to $31.2 \%$,

As a result of the evaluation of the parental material of rapeseed and mustard for resistance to Phoma rot in the field in all years of research, there was an absence of samples immune to the diseases. All sample were affected by Phoma rot to some extent (Table 2).

Table 2. The resistance of the breeding samples of winter rapeseed and winter brown mustard to Phoma rot

\begin{tabular}{|l|c|c|c|c|c|}
\hline \multirow{2}{*}{ Year } & \multicolumn{5}{|c|}{ The number of samples by resistance degree, \% } \\
\cline { 2 - 6 } & immune & resistant & $\begin{array}{c}\text { weakly re- } \\
\text { sistant }\end{array}$ & $\begin{array}{c}\text { weakly sus- } \\
\text { ceptible }\end{array}$ & susceptible \\
\hline \multicolumn{6}{|c|}{ Winter rapeseed } \\
\hline 2018 & 0 & 10.0 & 39.0 & 28.0 & 23.0 \\
\hline 2019 & 0 & 9.0 & 38.0 & 35.0 & 18.0 \\
\hline 2020 & 0 & 12.0 & 33.0 & 40.0 & 15.0 \\
\hline \multicolumn{7}{|c|}{ Winter brown mustard } \\
\hline 2018 & 0 & 5.0 & 63.0 & 11.0 & 15.0 \\
\hline 2019 & 0 & 3.0 & 47.0 & 32.0 & 18.0 \\
\hline 2020 & 0 & 6.0 & 55.0 & 30.0 & 9.0 \\
\hline
\end{tabular}

Against a high background of the Phoma rot prevalence during all years of research, we identified samples of winter rapeseed resistant to the disease with an affection degree of 1-2 points, their number was only $9.0-12.0 \%$ of the total number of examined samples. All other samples were weakly resistant with an affection degree of 3-4 points (33.0-39.0 \% of samples), weakly susceptible with an affection degree of 5-6 points (28.0-40.0\% of samples) and susceptible with an affection degree of 7-9 points (15.0-23.0\% of samples).

From our examination of winter brown mustard during the years of research, we also selected the samples resistant to Phoma rot. Their number is lower in comparison with rapeseed $03.0-6.0 \&$ of the total number of examined samples. The main part of the samples was weakly resistant with an affection degree of 3-4 points (47.0-63.0 \% of the total number of samples). The rest of the samples during the years of research were weakly susceptible with an affection degree of 5-6 points (11.0-30.0\%) and susceptible (9.0-18.0\%).

We will further study in the field against an artificial infectious background the identified samples of rapeseed and mustard, resistant to the affection by the Phoma rot pathogen with an affection degree of 1-2 points.

\section{Conclusions}

Against a high natural background, we selected a valuable parental material of winter rapeseed and winter brown mustard, resistant to the disease, which can be used as a donor of resistance to Phoma rot in breeding work during the development of new promising varieties. 


\section{References}

1. E. Woźniak, E. Waszkowska, T. Zimny, S. Sowa, T. Twardowski, Front Plant Sci., 10, 1423 (2019)

2. M. Rahman, A. Khatun, L. Liu, B.J. Barkla, Molecules, 23(1), 231 (2018)

3. J. Chen, X. Bian, G. Rapp, J. Lang, A. Montoya, R. Trethowan, B. Bouyssiere, J.F. Portha, J.N. Jaubert, P. Pratt, L. Coniglio, Industrial Crops and Products, 137, 597, (2019)

4. R. Szöllösi, Nuts and Seeds in Health and Disease Prevention (Second Edition), 357 (2020)

5. L.V. Samutenko, T.A. Milovskikh, Inter. Sci. Research J., 11-2 (77), 46 (2018)

6. O.A. Serdyuk, V.S. Trubina, L.A. Gorlova, Int. sci. and pract. conf. with elements of the school of young scientists "Scientific priorities of adaptive intensification of agricultural production", 172 (2019)

7. M.S. C Pedras, C.M Nycholat, S. Montaut, Y. Xu, Abdul Q Khan, Phytochemistry, 59(6), 611 (2002)

8. O.A. Serdyuk, Protection and quarantine of plants, 5, 21 (2012)

9. N. Zamani-Noor, J. Knüfer, Crop Protection, 112, 313 (2018)

10. M. Ijaz, B. Honermeier, Field Crops Research, 130, 80 (2012)

11. E.A. Voluevich, Proceedings of the National academy of Sci. of Belarus, biological series, 1, 119 (2017)

12. E.A. Voluevich, News of the national academy of Sci. of Belarus, biological series, $\mathbf{1}$, $101(2017)$

13. O.A. Serdyuk, V.V. Serdyuk, Int. sci.-pract. conf. "Sci. support of agricultural crops production in modern conditions", 189 (2016)

14. Species Fungorum, Global Species Databases (2020)

15. O.A. Serdyuk, V.V. Serdyuk, Int. sci.-pract. conf. "Sci. support for the production of rice and vegetable and melon crops in modern conditions", 181 (2016) 